\title{
Постуральний баланс у пацієнтів з гіпертонічною хворобою та деформуючими дорсопатіями шийного відділу хребта
}

\author{
1,2Колісник П. Ф., 1,2 Долинна О. В., 'Баранова І. В., 'Гончарова Н. С., \\ 1,2Колісник С. П., \\ ${ }^{1}$ Вінницький національний медичний університет імені М. І. Пирогова, м. Вінниця, Україна \\ ${ }^{2}$ Центр медичної реабілітації та спортивної медицини, м. Вінниця, Україна
}

Актуальність. Порушення постурального балансу (ПБ) у пацієнтів з гіпертонічною хворобою (ГХ) можуть виникати внаслідок підвищення артеріального тиску, побічних реакцій на ліки, ураження органів-мішеней, супутніх захворювань, зокрема патології шийного відділу хребта (ШВХ). Деформуючі дорсопатії (ДД) ШВХ також сприяють виникненню порушень ПБ за рахунок змін кровотоку у вертебробазилярному басейні.

Мета: вивчити відмінності стабілометричних показників ПБ у пацієнтів з ГХ та ДД ШВХ.

Матеріали та методи. Обстежено 16 пацієнтів з ГХ та ДД ШВХ (середній вік $43,9 \pm 10,0$ років). ДД діагностовано за допомогою рентгенографії ШВХ. ПБ оцінювався під час аналізу стабілометричних показників, отриманих за допомогою силової платформи. Вимірювання проводилось у біподальній позиції з відкритими очима протягом 30 секунд до виконання фізичних вправ та після фізичного навантаження. Визначено відхилення тіла у сагітальній (ВСП) та фронтальній площинах (ВФП), середне відхилення (СВ) від центру. Статистичний аналіз отриманих даних проведено за допомогою програми SPSS. Різниця рівня о3нак розрахована за допомогою U-критерію Манна - Уїтні.

Результати та іх обговорення: Виявлена статистично значима різниця рівня ВСП, ВФП, СВ до виконання фізичних вправ та після фізичного навантаження. Результати представлені в таблиці 1.

Висновки. Встановлено достовірне покращення показників постурального балансу у пацієнтів з ГХ та осіб з нормальним артеріальним тиском до виконання фізичних вправ та після фізичного навантаження.

Перспективи подальших досліджень. Дослідження являється фрагментом дисертаційної наукової роботи та науководослідної роботи кафедри. Продовжується обстеження пацієнтів та вивчення особливостей ПБ у пацієнтів з ГХ, іх значення під час створення реабілітаційних програм.

Ключові слова: постуральний баланс, стабілометрія, гіпертонічна хвороба, деформуючі дорсопатії.

Конфлікт інтересів. Автори заявляють про відсутність конфлікту інтересів.

\begin{tabular}{ccc}
\hline Показники стабілометрії & До фізичного навантаження & Після фізичного навантаження \\
\hline ВСП & $\mathrm{U}=26^{*}$ & $\mathrm{U}=23,5^{*}$ \\
\hline $\mathrm{BФП}$ & $\mathrm{U}=25^{*}$ & $\mathrm{U}=32^{* *}$ \\
\hline $\mathrm{CB}$ & $\mathrm{U}=21^{*}$ & $\mathrm{U}=18,5^{*}$ \\
\hline
\end{tabular}

${ }^{*} \mathrm{p} \leq 0,01 ;{ }^{* *} \mathrm{p} \leq 0,05$ 